\title{
An analysis of students' reading difficulties; a study at the first grade of SMKN 1 Simpang Pematang
}

\author{
Anggun Khoirun Nisak ${ }^{1}$, Ujang Suparman ${ }^{2}$, Ramlan Ginting ${ }^{3}$ \\ Universitas Lampung, Jl. Prof. Dr. Sumantri Brojonegoro, Rajabasa, Bandar Lampung ${ }^{1,2,3}$ \\ Correspondence: anggunkhoirunisak17@gmail.com
}

\begin{abstract}
This research aims to find out the students' difficulties faced in comprehending English reading text and to know the factors of contributing to the students' difficulties in comprehending English reading text. Furthermore, in this research used a descriptive qualitative study. In collecting the data, the researcher used reading test and interview. The data were analyzed based on five classifications to find out students' difficulties in reading comprehending and four factors of contributing to the students' difficulties. The result of this study showed that there were difficulties were faced by students in their reading, namely determining main idea 63 mistakes (16.4\%), understanding vocabulary 89 mistakes $(23.1 \%)$, making inference 88 mistakes (22.9\%), locating reference 86 mistakes $(22.3 \%)$, and detail information 59 mistakes $(15.3 \%)$. In addition, based on students' interview result, the factors of contributing to the students' difficulties in comprehending English reading text were students' background, vocabulary problem, sentence problem, and rhetorical structure. In this case, by knowing the students' difficulties in comprehending English reading text, the English teacher should learn better and be more creative in applying the techniques of teaching reading skill. It is used to solve the students' difficulties in comprehending the reading text.
\end{abstract}

Keywords: Comprehending, reading text, reading difficulties.

\section{INTRODUCTION}

Reading is one of the four language skills taught in most schools; besides speaking, listening, and writing. Reading is one of the most important skills students need to master as it enables them to understand what the text tells about. This skill cannot be separated from the other language skills because it will support students to master other skills. For example, when someone intends to speak in public, firstly they should know the information by reading the text. Reading is a receptive skill, it means we receive information or we gain something from this skill. William (1984) says reading as a process where one looks at and understands what has been written. Everyone who reading a text, they are in the process to get something from the text.

Based on the curriculum 2013, the objective of teaching reading for the first grade of SMK students is to enable the students' to identify the main idea of the whole text, vocabularies, and some information of a reading text. Grabe (2002) defines reading as a complex ability to extract, build meaning from a text. In short, reading is generally defined as a process of identifying a written or printed text to understand its meaning. From reading, everyone will acquire the level in understanding of the text in order to build their comprehension ability.

Talking about comprehension, it must be known that reading comprehension is the level of students' ability to understand and get the hidden meaning from the text. By reading we will answer what, why, who, where, when and how about the text. Reading comprehension is the interaction between the reader and the text in a meaningful way. In reading comprehension we must also be familiar with reading sub skills. Nuttal (1982) states there are five short reading skills that should be mastered by reader to comprehend a text deeply. As Suparman (2012) states that there are several aspects of reading 
comprehension skills that should be mastered by reader to comprehend the text in order to get the information that is written, including identifying the main idea, finding inference, finding reference, recognizing the detailed information, and discovering the meaning of vocabularies in the reading texts.

Many previous studies have analyzed about students' difficulties in comprehension reading text. First research was conducted by Dwianasari (2015) which discussing students` problems on reading comprehension. Larasati (2019) also conducted similar research about an analysis of difficulties in comprehending english reading text. Based on their researches, it was shown that students had difficulty in vocabulary, because of student limited vocabulary. This is one type of students' difficulties in reading comprehension.

Based on the researcher's experience during PLP in SMKN 1 Simpang pematang, it was found several difficulties encountered by the students. The teacher says that the students get some problem in understanding word, phrases and English text. Therefore, the difficulties in comprehending the texts have been the main focused in this research.So, that is why the researcher wants to analyze the difficult aspect of reading comprehension text. Reading comprehension difficulty occurs frequently. This difficulty occurs for many reasons, the three most important ones are vocabulary, working memory, absence of extensive reading and the laziness to read a text. From those problems, it is important to encourage students' reading comprehension, especially foreign language students to read as much as possible because in this way they will find a great help in their language learning process.

Based on the explanation above, reading comprehension is important in language as a result of the student will get information, ideas, and knowledge. It will make a case for that reading is that the combination of word recognition, intellect, and emotions reticulated with previous knowledge to understand the text. The researcher aims to find out the difficulties face in comprehending English reading text and to know the factors of contributing to the students' difficulties in comprehending English reading text will face by the first grade students' of SMKN 1 Simpang Pematang.

\section{METHODS}

The kind of this research was descriptive qualitative. Qualitative approach in research is concerned with subjective assessment of attitudes, opinions and behavior (Kothari: 2004). Suparman (2009) states that qualitative researchers report the result obtained from qualitative analysis through detailed descriptions of the processes which the researchers used in arriving at the categories and patterns of the research. In this research descriptive was a conducted in the purpose to describe systematically about the fact and characteristics of the subject. In this study, the researcher aims to find out the difficulties face in comprehending English reading text and to know the factors of contributing to the students' difficulties in comprehending English reading text. The researcher analyzed students' difficulties in reading by Nuttall's (1982) classification, they were determining main idea, finding reference, making reference, understanding vocabulary and detail information. Then, there were four factors that researcher used to analyzed the students' difficulties in comprehending English reading text, they were students' background, vocabulary problem, sentence problem, and rhetorical structure (Sutarsyah: 2013).

The participant of this research was the students of the first grade at SMKN 1 Simpang Pematang in the 2020/2021 academic year. The researcher chose the first grade at SMKN 1 Simpang Pematang as the participant because in the thirteenth curriculum (K13), first grade in senior high school students were required to study descriptive text in the first semester.There are four majors at the first grade of SMKN 1 Simpang Pematang, they were X ATP (Agribisnis Tanaman Perkebunan), X TKR (Teknik Kendaraan Ringan), X Akuntansi, dan X TKJ (Teknik Komputer dan Jaringan). Researcher would choose X TKJ using purposive sampling to determine the research sample. Purposeful sampling was a technique widely 
used in qualitative research for the identification and selection of information-rich cases for the most effective use of limited resources. The researcher choose X TKJ for sample of the research, because the class was in accordance with the objectives to achieved by the researcher.

In conducting this research, the researcher used reading test and interview as the instruments. The researcher asked students to answer 25 questions of reading test to be analyzed the students' difficulties in comprehending English reading text. Then the researcher conducted interviews with the students to find out the factors were contributing to the students' difficulties in comprehending English reading text. The researcher used guided interviews with 16 questions in order to get deeper information and in accordance with the researcher's purposes.

After collecting the data, the researcher reducing the data. It means, the researcher chose the important data that had been collected. Then, The researcher categorized the student comprehension of the reading textby looking Nuttall (1982) classification. And getting the appropriated percentage from the student comprehension of the reading text. To get the percentage the researcher used the following formula:

\section{P: Percentage \\ F: Frequency of Difficulties \\ $\mathrm{N}$ : Number of Aspect}$$
\mathbf{P}=\frac{\mathrm{F}}{\mathrm{N}} \mathbf{x} \mathbf{1 0 0 \%}
$$

100: Permanent Number

After the researcher analyzed the students' difficulties in reading text, the researcher would analyze the interviews result from each participant. In analyzing the results of the interview, the researcher would transcribe the results of the verbal interview into written form. After that the researcher would classified students' perceptions into several types depending four factors are contributing to the difficulties in comprehending English reading text based on Sutarsyah (2013) classification.

In this research, the researcher used a qualitative descriptive research. According to Setiyadi (2006) stated that in qualitative research, the ability of researchers to collect data is needed because the role of researchers such as analyzing and interpreting data will determine the quality of the data collected. The researcher used the triangulation of method to get validity of the data. It was comparing and checking the validity of the data collected in different time and technique of data collection. The researcher evaluated the data which were collected by test and interview. The test was collected from me myself that has given to the students. The researcher interviewed the students in that school about the students' difficulties in comprehension of the reading text. The researcher used the data from interview and the test was taken from the students test as the implementation of method triangulation.

\section{RESULTS AND DISCUSSIONS}

\section{Results}

The result showed that the total difficulties which made by students in reading test were three hundred and eighty five mistakes. There were five types of the students' difficulties in comprehending English reading text. They were determining main idea 63 mistakes with the percentage of $16.4 \%$, understanding vocabulary 89 mistakes with the percentage of $23.1 \%$, making inference 88 mistakes with the percentage of $22.9 \%$, locating reference 86 mistakes with the percentage of $22.3 \%$, and detail information 59 mistakes with the percentage of $22.3 \%$. Here is the tabulation of difficulties made by each student: 
Table 1. The Classification of Students' Difficulties

\begin{tabular}{|c|c|c|c|c|c|c|}
\hline No. & $\begin{array}{c}\text { Student's } \\
\text { Initial } \\
\text { Name }\end{array}$ & $\begin{array}{l}\text { Determining } \\
\text { Main Idea }\end{array}$ & $\begin{array}{l}\text { Understanding } \\
\text { Vocabulary }\end{array}$ & $\begin{array}{c}\text { Making } \\
\text { Inference }\end{array}$ & $\begin{array}{l}\text { Locating } \\
\text { Reference }\end{array}$ & $\begin{array}{c}\text { Detailing } \\
\text { Information }\end{array}$ \\
\hline 1. & FR & 4 & 5 & 4 & 3 & 2 \\
\hline 2. & $\mathrm{AK}$ & 2 & 2 & 2 & 2 & 2 \\
\hline 3 & AN & 1 & 3 & 3 & 2 & 0 \\
\hline 4. & DPS & 3 & 4 & 3 & 3 & 1 \\
\hline 5. & $\mathrm{AJH}$ & 3 & 4 & 4 & 4 & 4 \\
\hline 6. & AA & 2 & 4 & 3 & 3 & 1 \\
\hline 7. & DR & 3 & 3 & 4 & 3 & 3 \\
\hline 8. & AAP & 4 & 3 & 4 & 3 & 2 \\
\hline 9. & $\mathrm{FH}$ & 3 & 2 & 2 & 3 & 2 \\
\hline 10. & DA & 3 & 5 & 2 & 3 & 2 \\
\hline 11. & FLR & 3 & 5 & 3 & 3 & 1 \\
\hline 12. & EK & 3 & 4 & 4 & 4 & 2 \\
\hline 13. & IWS & 1 & 4 & 3 & 5 & 2 \\
\hline 14. & RWD & 3 & 4 & 5 & 3 & 2 \\
\hline 15. & RDV & 3 & 4 & 3 & 4 & 4 \\
\hline 16. & TL & 1 & 4 & 2 & 3 & 3 \\
\hline 17. & $\mathrm{PF}$ & 3 & 3 & 3 & 3 & 3 \\
\hline 18. & MM & 3 & 3 & 3 & 5 & 3 \\
\hline 19. & $\mathrm{KW}$ & 3 & 3 & 4 & 4 & 2 \\
\hline 20. & $\mathrm{ME}$ & 3 & 3 & 5 & 4 & 3 \\
\hline 21. & $\mathrm{SH}$ & 3 & 2 & 5 & 3 & 3 \\
\hline 22. & MH & 1 & 5 & 5 & 4 & 4 \\
\hline 23. & LA & 2 & 2 & 3 & 5 & 3 \\
\hline 24. & IC & 2 & 3 & 5 & 4 & 2 \\
\hline 25. & LC & 1 & 5 & 4 & 3 & 3 \\
\hline \multicolumn{2}{|c|}{$\begin{array}{c}\text { Total of each } \\
\text { difficulties }\end{array}$} & 63 & 89 & 88 & 86 & 59 \\
\hline \multicolumn{2}{|c|}{$\begin{array}{l}\text { Total of all } \\
\text { difficulties }\end{array}$} & \multicolumn{5}{|c|}{385} \\
\hline
\end{tabular}

Below was a pie chart of the number of difficulties made by students based on the aspects of students' difficulties in comprehending English reading text.

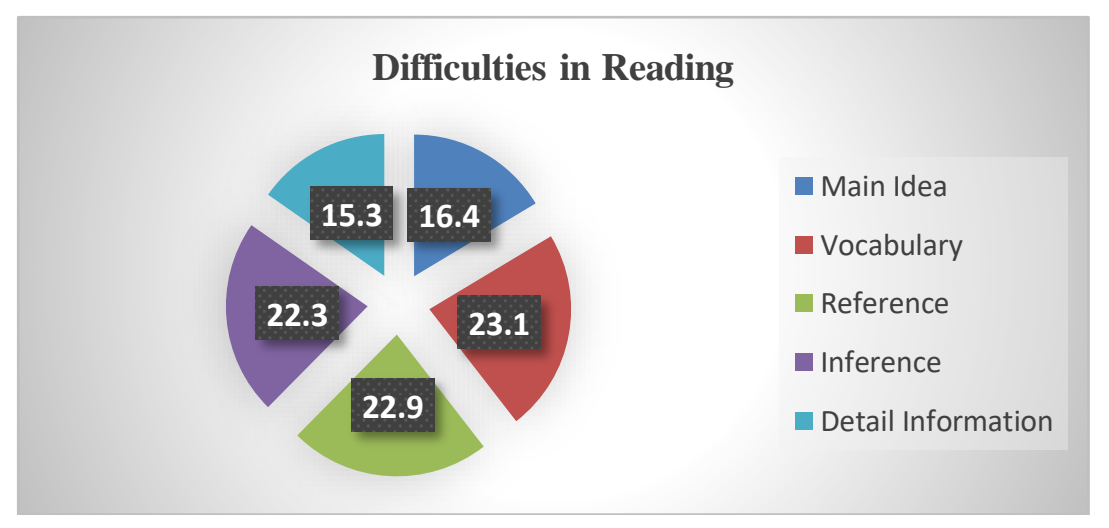


Based on the chart above, the researcher can describe the percentage of students' difficulties in reading text. The total of errors is 385 difficulties. Furthermore, the percentage of determining main idea is $16.4 \%$, the percentage of understanding vocabulary $23.1 \%$, the percentage of making inference $22.9 \%$, the percentage of locating reference $22.3 \%$, and the percentage of detail information is $15.3 \%$. Moreover, the table provides evidence that understanding vocabulary is the highest difficult whereas detail information is the lowest difficult made by the students.

In this section, the researcher describes the results of students' interviews. To know the factors of contributing to the students' difficulties in comprehending English reading text, the researcher identified several types of factors they were students' background, vocabulary problem, sentence problem, and rhetorical structure. Then, the researcher conducted an interview to find out students' difficulties. There were 16 questions in interview and the researcher classified the result into four categories.

The first factor of contributing the students' difficulties in comprehending English reading text was students' background. The students had been studying English since they were in kindergarten, elementary school, and junior high school. Even though they have learned English from a young age, only a few students liked English. Students who liked English also find it very difficult to master English.

The second factor of contributing students' difficulties in comprehending English reading text was vocabulary problem. There were 3 out of 10 children who felt that vocabulary was an aspect of reading that difficult to be mastered. In fact, the vocabulary problem was the second aspect that many students make mistakes. Many of them said that they didn't know the meaning of the vocabulary so they made mistakes. One student said that "I ever know but forget".

The third factor of contributing students' difficulties in comprehending English reading text was sentence problem. Actually, the students cannot understand if the sentences are complex. When the researcher asked the students "Do you have difficulty reading long texts or sentences?" many of them answered confidently "Yes." or "Yes very difficult."

The last factor of contributing students' difficulties in comprehending English reading text was rhetorical structure. Students found it difficult to understand rhetorical structures. There are 6 out of 10 students mentioned that they had difficulty in the aspect of writing, namely locating references. Locating reference was included in the rhetorical structure in the factor of contributing students' difficulties in comprehending English reading text. A student said, "Not really understand about reference".

Based on result interview, the students experience difficulties in comprehending English reading text based on the factor of contributing students' difficulties in comprehending English reading text, namely students background, vocabulary problem, sentence problem, and theoritical structure.

\section{Discussions}

\section{The difficulties were faced by students' in comprehending English reading text}

In the previous subchapter, the data were taken from the results of the students' reading tests. To find out the description of students' difficulties in reading, the researcher identified several types of aspects of reading, they were determining main idea, finding reference, making reference, understanding vocabulary and detail information. They were classified by Nuttal (1982).

There were 385 difficulties were faced by students' in comprehending English reading text. From 5 types of students' difficulties in reading, understanding vocabulary had the highest number. The students' made 89 incorrect answer of understanding vocabulary with the percentages of $23,1 \%$. The students made many mistakes in vocabulary questions because of their lack in vocabulary. It was in line with Larasati (2019), the students cannot understand what the text is about because they do not know the meaning of the word. 
Because students lack knowledge of vocabulary so they could not understand the content of the text and they had difficulty in answering questions. The students should learn and increase their mastery of the vocabulary so that they could understand a reading.

The second most difficult faced by the students in comprehending English reading text was making inference with the total number 88 incorrect answer and the percentages $21,8 \%$. In this types of students difficulties in comprehending English text because of the students did not really understand about the text, then they could not make a logically conclusion based on the text. Many of the other researchers also found that making inference was types that have high difficulty so that students could not answered a related question. It was in line with Fauzia (2019) findings, the researcher concluded three difficulties they are determining main idea, making inference and detail information which has low score.

The third most difficult faced by the students in comprehending English reading text was locating reference with the total number 86 incorrect answer and the percentages $21,8 \%$. According to Nuttall (1982), reference is the intentional use of one thing to indicate something else in which one provides the information necessary to interpret the other. According to Nuttall statement, the students should understood one sentence to understand other sentences in the text. Therefore, when students found questions like "It refers to..." they could not answer it because of lack understanding about the text. It would happen also because of lack in grammar, they did not really understand about structure of the sentence.

The fourth most difficult faced by the students in comprehending English reading text was determining main idea with the total number 63 incorrect answer and the percentages 16,4\%. Many students had difficulties in finding the main idea. It was caused by their lack in comprehending the text and could not guess the main idea of the text. Actually, they comprehended the text but they did not know where the main idea was.

The last most difficult faced by the students in comprehending English reading text was detail information with the total number 59 incorrect answer and the percentages $15.3 \%$. The lowest number of type students' difficulties in reading was detail information. It was in line with Larasati (2019) findings, the lowest types of students who are difficulties in answering question items to look for the detail information. Even so there were some students still felt confused in this type. So, the students should study hard in understanding the text to find the detail information.

Based on students' result in reading test the researcher found that five aspects of the difficulties were faced by students' in comprehending English reading text, they were determining main idea, finding reference, making reference, understanding vocabulary and detail information.

\section{The factors were contributing to the difficulties in comprehending English reading text}

After categorizing the students result interview, the researcher concluded that in the first grade students' at SMKN 1 Simpang Pematang, the students faced difficulty in comprehending English reading text. There were several factors are contributing to the difficulties in comprehending English reading text, they were students' background, vocabulary problem, sentence problem, and rhetorical structure. They were classified by (Sutarsyah: 2013).

First, students' background was the factor of contributing the difficulties in comprehending English reading text. Every student had different background knowledge. Students' background could be seen from how long they have studied English and how interested they were in English. It was in line with Westwood (2001) said that the learners' background related with the learner attitude toward reading, such as interest and motivation in reading and the prior knowledge that the learner has known before. Based on 
the interview results, even students who had been studying English for a long time had no interested, so their motivation in learning reading was very small.

Second, the factor of contributing the difficulties in comprehending English reading text was vocabulary problem. The students made many mistakes in answering questions about the vocabulary and they even had difficulty understanding a text because they did not know the meaning of the vocabulary. From the results of the interview students, they said that they were wrong in answering because they did not know the meaning. Many students answer vocabulary questions by guessing or asking their friends because of the difficulty in understanding the meaning. It was in line with Larasati (2019), they needed to look for the meaning of the vocabulary in the dictionary. When students did not know the meaning of a vocabulary, they were very dependent on the dictionary or asking to the teacher.

Third, sentence problem was the factor of contributing the difficulties in comprehending English reading text. Based on result of students' interview, they had difficulties in understanding long sentences and finding main idea. Because the difficulty they felt, therefore it is included in the sentence problem category. When they had difficulty understanding a text, it made them unable to make an inference even the students could not comprehend the text. It was in line with Sutarsyah (2013) findings, the students' problem in terms of sentence or grammatical structure was classified into seven categories, understanding complex sentences, making chunks, understanding long phrases, understanding sentence relation, grammatical problems, finding main idea, and passage organization.

Fourth, the last factor of contributing the difficulties in comprehending English reading text was rhetorical structure. In this categorize the students said that they had difficulties in locating references and identify the text. When they got questions about a reference and they failed to understand the text, they often only guessed when they answer the questions. As stated by Sutarsyah (2013), they had difficulty to see this relation so that they could not see a text as a unified whole. In a text must have a unity between one sentence and others. This was one of the difficulties faced by students so that they found it difficult to understand the text.

Based on the result of students' interview, there were four factors are contributing to the difficulties in comprehending English reading text, they were students' background, vocabulary problem, sentence problem, and rhetorical structure. Students' difficulties in their background knowledge was their interest in studying English. Vocabulary problem that faced by the students because they did not know the meaning of the vocabulary and lack of knowledge in vocabulary. Sentence problem happened because the students had difficulties in understanding long sentences. Then, students' difficulties in rhetorical structure was because they could not understand information of the text. The students should study hard in comprehending reading text to reduce the difficulties they faced and so that they could master reading skills.

\section{CONCLUSIONS}

After analyzing the result of the students' difficulties and the factors are contributing to the difficulties in comprehending English reading text at the first grade students of SMKN 1 Simpang Pematang, the researcher draws the conclusion based on the result of analyzing the data. Based on analyzed data there were five types of the students' difficulties in comprehending English reading text. They were determining main idea 63 mistakes with the percentage of $16.4 \%$, understanding vocabulary 89 mistakes with the percentage of $23.1 \%$, making inference 88 mistakes with the percentage of $22.9 \%$, locating reference 86 mistakes with the percentage of $22.3 \%$, and detail information 59 mistakes with the percentage of $22.3 \%$. In addition, from the result of students' interview, the researcher found four factors causing the students difficulties in comprehending English reading text. There were students' background, 
vocabulary problem, sentence problem, and rhetorical structure. Students' difficulties in their background knowledge was about their interest in studying English. Vocabulary problem that faced by the students because they did not know the meaning of the vocabulary and lack of knowledge in vocabulary. Sentence problem happened because the students had difficulties in understanding long sentences. Then, students' difficulties in rhetorical structure was because they could not understand information of the text.

\section{REFERENCES}

Dwianasari, N. (2015). Students' problems on reading comprehension at an islamic junior high school in Sungai Bahar. Jambi University.

Fauzia, S. (2019). A descriptive analysis of students' difficulties in comprehending English reading text (A case study of the second semester of English Department students in IAIN Salatiga in academic year of 2018/2019). Doctoral dissertation, IAIN Salatiga.

Grabe, W. (2002). Dilemma for the development of first language reading abilities. In J.C.Richards \& W. A. Renandya (Eds). Methodology in language teaching. Cambridge: Cambridge University Press.

Kothari, C. R. (2004). Research methodology: Method and techniques. New Delhi: New Age International (P) limited publishers.

Larasati, D. (2019). An analysis of difficulties in comprehending English reading text at the eleventh grade students of Ma Lab Uin-Su Medan, Medan: State Islamic University of North Sumatera Medan.

Nuttall, C. (1982). Teaching reading skills in a foreign language. Oxford: of educational research, 61, 239-264.

Setiyadi, B. (2006). Metode penelitian untuk pengajaran bahasa asing pendekatan kualitatif dan kuantitatif. Yogyakarta : Penerbit Graha Ilmu.

Suparman, U. (2009). Qualitative research for language teaching and learning. Bandung: Arfino Raya Publisher.

Suparman, U. (2012). Developing reading skills and strategies. Bandung: CV. Alfino Raya.

Sutarsyah, C. (2013). Reading theories and practice. Bandar Lampung: Lembaga Penelitian Universitas Lampung.

Westwood, P. S. (2001). Reading ang learning difficluties: Approaches to teaching and assessment. Camberwell: The Australian Council for Educational Research Ltd.

William. (1984). Succes in reading comprehension. Hempstead: New Orleans. 